Endocrinol. Japon. Vol. j, No. 4 (1958)

\title{
STUDIES ON THE SALIVARY GLAND HORMONE XXXV* INFLUENCE OF TRYPSIN ON PAROTIN (2)
}

\author{
YOSOJI ITO AND MASATO SHINODA \\ Department of Physiological Chemistry, Faculty of Pharmaceutical Sciences, \\ University of Tokyo
}

The chemical and physico-chemical properties of Parotin, a salivary gland hormone, were reviewed by Ito (1954). Parotin is a protein of the globulin type, whose isoelectric point is found approximately as $\mathrm{pH}$ 5.4. The ultraviolet absorption spectrum of it at $\mathrm{pH} 7.0$ solution is the one of the typical protein with a maximum at $277 \mathrm{~m} \mu$, while in alkaline solution it shifts to longer wave length. The extinction of ultraviolet absorption of Parotin at $277 \mathrm{~m} \mu$ shows a proportional relationship with the concentration of Parotin within the range from $0.1 \mathrm{mg}$ per $\mathrm{ml}$ to $0.8 \mathrm{mg}$ per $\mathrm{ml}$.

In the previous publication (Ito and Shinoda, 1958), it was reported that the serum calcium decreasing activity of Parotin was slowly diminished and almost destroyed after digestion for $24 \mathrm{hrs}$. with trypsin, and the decreasing activity on the number of circulating leucocytes was rapidly adminished, while the increasing activity of leucocytes was relatively resistant to the action of trypsin, and remained even after digestion for $24 \mathrm{hrs}$.

This paper deals with the changes of the chemical and physico-chemical properties of Parotin by the tryptic digestion.

\section{METHODS}

\section{Tryptic digestion of Parotin}

The trypsin used in this experiment was a crystalline preparation, having the activity as 1600 haemoglobin units per $\mathrm{mg}$ by the method of Anson (1938).

The Parotin used was extracted from fresh bovine parotid gland and purified by the method of Ito and Mizutani (1952). The purity of this preparation was electrophoretically estimated as $87.5 \%$.

One handred $\mathrm{mg}$ of Parotin was dissolved in $10 \mathrm{ml}$ of distilled water, adjusted to $\mathrm{pH} 8.0$ with $0.1 \mathrm{~N} \mathrm{NaOH}$, and then $2 \mathrm{mg}$ of trypsin was added. The same quantities of Parotin was dissolved similarly without the enzyme and used as control. Both solutions with and without the enzyme were incubated at $37^{\circ} \mathrm{C}$. After the incubation, the incubated solutions were taken and cooled in ice water.

\section{Determination of free amino-nitrogen content}

Two $\mathrm{ml}$ of Parotin solution digested by trypsin was taken, and $2 \mathrm{ml}$ of acetic acid was added. The free amino-nitrogen contents in this solution was determined by Van Slyke method.

Received for publication June 30, 1958.

* XXXV: Y. Ito and M. Shinoda (1958). Endocrinol. Japon. 5, 221.

This study has been carried out with the assistance of Grant in Aid for Scientific ResearchInstitutional Research from the Ministry of Education. 


\section{Determination of ultraviolet absorption spectrum}

Ten $\mathrm{ml}$ of the Parotin solution incubated with trypsin was diluted to $25 \mathrm{ml}$ with cold distilled water (Parotin conc. 0.4\%). One $\mathrm{ml}$ of this diluted solution was taken in 3 test tubes (A, B and $\mathrm{C})$. To the tube $\mathrm{A}, 1 \mathrm{ml}$ of glacial acetic acid was added to stop the proteolysis. Then, $6 \mathrm{ml}$ of distilled water was added (Sample A). To the tube B, $7 \mathrm{ml}$ of $0.1 M \mathrm{pH} 5.4$ acetate buffer was added and mixed completely. The produced precipitate was centrifuged, and the supernatant solution was taken (Sample B). To the tube $\mathrm{G}, 1 \mathrm{ml}$ of $10 \%$ trichloroacetic acid was added and completely mixed. The resulted precipitate was centrifuged. Then $1 \mathrm{ml}$ of the supernatant solution was taken and $3 \mathrm{ml}$ of distilled water was added (Sample G). The Parotin solution incubated without trypsin was treated in the same manner as stated above and used as control.

The ultraviolet absorption of thus treated solutions were determined by a Beckman spectrophotometer at room temperature.

Paper chromatography

Some drops of Parotin solution digested by trypsin was taken and the equal volume of acetic acid was added. This solution was submitted to paper chromatography by the onedimensional ascending method with No. 50 Toyo Roshi filter paper, using the mixture of $n$ butanol-acetic acid-water $(4: 1: 5)$ as the solvent, and ninhydrin as the coloring reagent.

The equal volume of $10 \%$ trichloroacetic acid was added to the Parotin solutions digested by trypsin for 1, 4, and $24 \mathrm{hrs}$. and then the mixtures were centrifuged. Then, the supernatant solutions were taken and submitted as non-protein fraction in digested Parotin.

\section{RESULTS}

\section{Influence of trypsin on amino-nitrogen contents in Parotin.}

The free amino-nitrogen contents in Parotin digested by trypsin for 1, 2, 3, and 24 hrs. were determined as shown in Figure 1. In the tryptic digestion, the

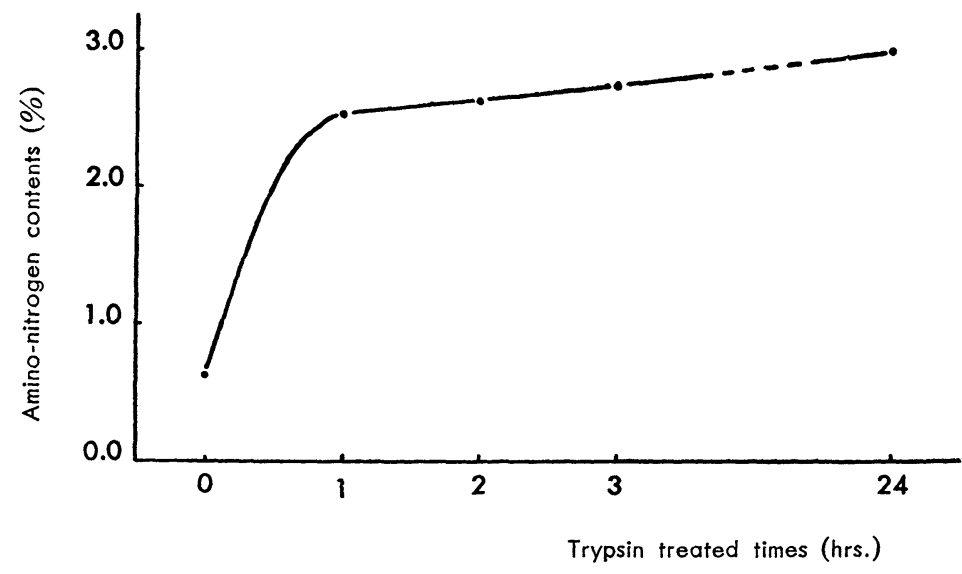

Fig. 1. Influence of trypsin on amino-nitrogen contents of Parotin

amino-nitrogen content in Parotin was rapidly increased within $1 \mathrm{hr}$. as compared with control before the incubation. However, this increase was very slight after 1 hr inmotion un to 24 hrs. 


\section{Influence of trypsin on ultraviolet absorption spectrum of Parotin}

The ultraviolet absorption spectra of control Parotin before incubation and incubated Parotin with and without trypsin for $0.5,1,2,3,5$, and 24 hrs. were determined as shown in Figure 2 and Table 1.

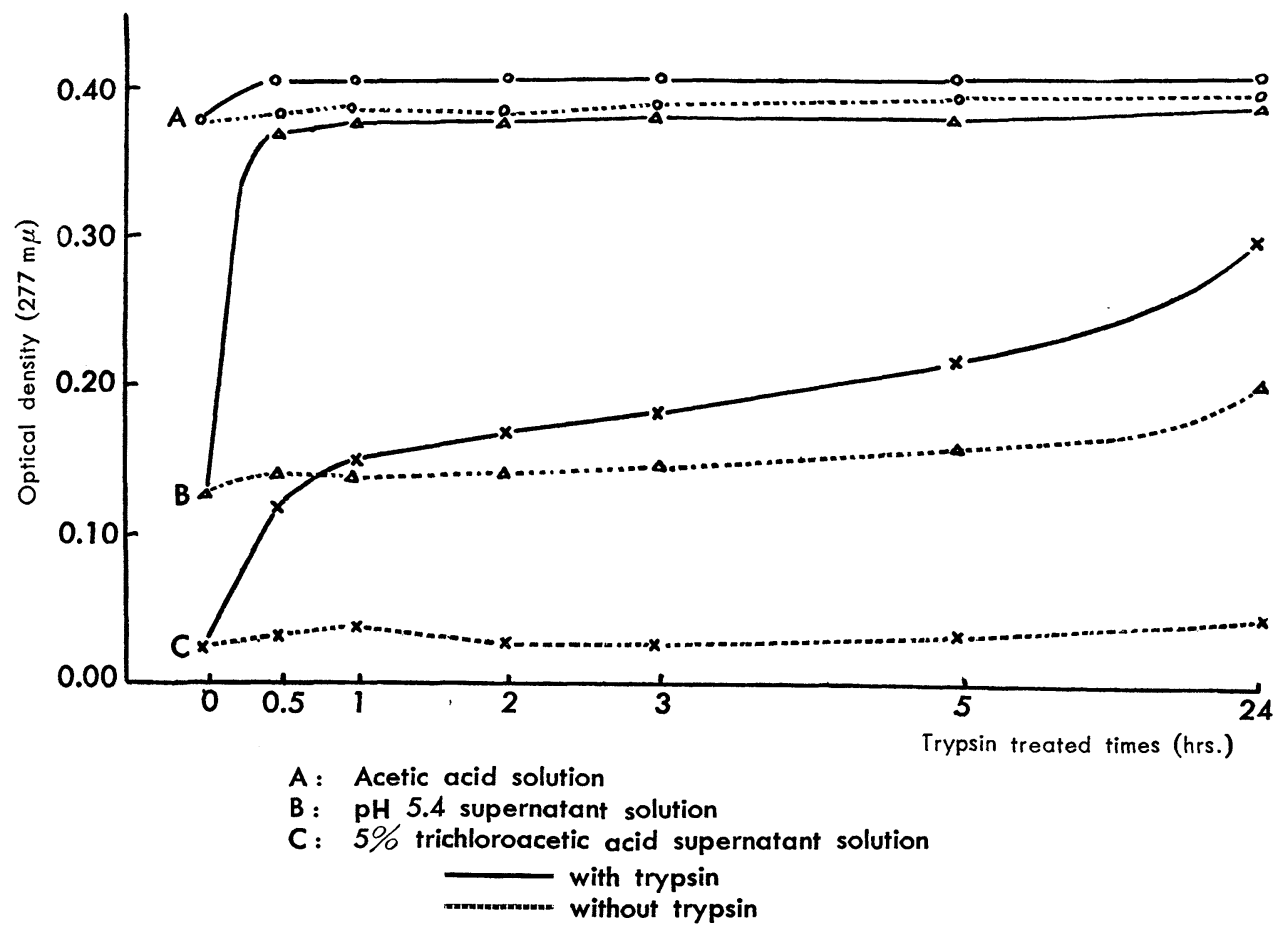

Fig. 2. Influence of trypsin on ultraviolet absorption spectra of Parotin

Table 1. Relation between the trypsin digested times and the maximum wave length of ultraviolet absorption spectra of Parotin

\begin{tabular}{|c|c|c|c|c|c|c|}
\hline \multirow{3}{*}{$\begin{array}{c}\text { Incubated } \\
\text { time } \\
\text { (hr.) }\end{array}$} & \multicolumn{6}{|c|}{ Maximum wave length of ultraviolet absorption spectra } \\
\hline & \multicolumn{2}{|c|}{ Sample A } & \multicolumn{2}{|c|}{ Sample B } & \multicolumn{2}{|c|}{ Sample C } \\
\hline & $\begin{array}{l}\text { Without } \\
\text { trypsin }\end{array}$ & $\begin{array}{l}\text { With } \\
\text { trypsin }\end{array}$ & $\begin{array}{l}\text { Without } \\
\text { trypsin }\end{array}$ & $\begin{array}{l}\text { With } \\
\text { trypsin }\end{array}$ & $\begin{array}{l}\text { Without } \\
\text { trypsin }\end{array}$ & $\begin{array}{c}\text { With } \\
\text { trypsin }\end{array}$ \\
\hline 0 & $277 \mathrm{~m} \mu$ & $-m \mu$ & $274 \sim 276 \mathrm{~m} \mu$ & $-m \mu$ & $276 \mathrm{~m} \mu$ & $-\mathrm{m} \mu$ \\
\hline 0.5 & 277 & 276 & 276 & 276 & 275 & $276 \sim 277$ \\
\hline 1 & 277 & 276 & 276 & 276 & $<274$ & $276 \sim 277$ \\
\hline 2 & 277 & 276 & 276 & 276 & $<274$ & 276 \\
\hline 3 & 277 & 275 & 276 & 276 & $<274$ & 276 \\
\hline 5 & 277 & 275 & 276 & 276 & $<274$ & 276 \\
\hline 24 & 276 & 275 & 277 & 276 & $<274$ & 276 \\
\hline
\end{tabular}

In the case of sample $\mathrm{A}$, the extinction of Parotin digested by trypsin were increased after $0.5 \mathrm{hr}$. incubation, however, the increase for 1 to $24 \mathrm{hrs}$. incubation were very slight. The extinction of Parotin incubated without trypsin were 
consistently remained as control before incubation without any change. In the case of sample B, the digested Parotin did not precipitate at $\mathrm{pH} 5.4$ after incubation, and the extinction of $\mathrm{pH} 5.4$ supernatant solutions of digested Parotin were showed nearly the same level as control of sample A. Therefore, it was found that the initial isoelectric point $(\mathrm{pH}$ 5.4) of Parotin was easily changed by the incubation with trypsin, however, the isoelectric point of Parotin without enzyme did not. Recently, it was found that the Parotin incubated with trypsin was precipitated at $\mathrm{pH} 4.5$ as isoelectric point by the adjustment of $\mathrm{pH}$ (Ito and Shinoda, 1958, in press). In the case of sample $\mathrm{C}$, the increase of non-protein fraction produced by the tryptic digestion of Parotin were determined.

The maximum wave length of the ultraviolet absorption spectrum of Parotin was slightly removed to the side of shorter wave length by the tryptic digestion. Paper chromatography of the Parotin digested by trypsin

The result of paper chromatogram of the digested Parotin was shown in Figure 3. The hydrolyzates produced by the tryptic digestion of Parotin were recognized at Rf 0.08 and 0.13 . The control Parotin or the enzyme themselves were respectively not developed with this solvent. The result of chromatogram of trichloroacetic acid solutions were shown in Figure 4, and these two hydrolyzates were similarly recognized as Figure 3. Therefore, these hydrolyzates in the Parotin digested by trypsin were soluble in 5\% trichloroacetic acid and were comprised in non-protein fraction.

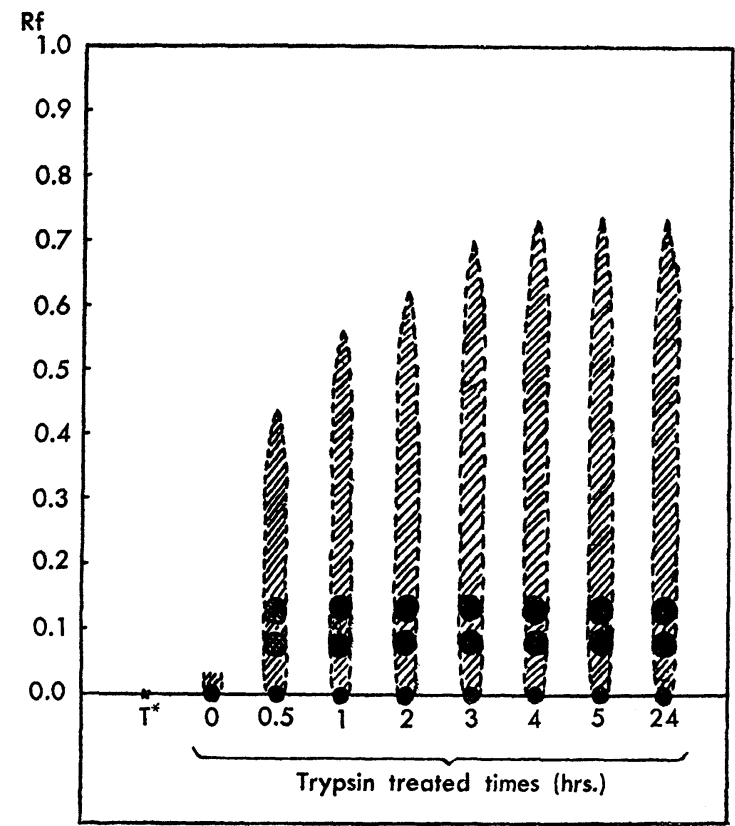

* Trypsin solution

Fig. 3. Paperchromatogram of Parotin digested by trypsin

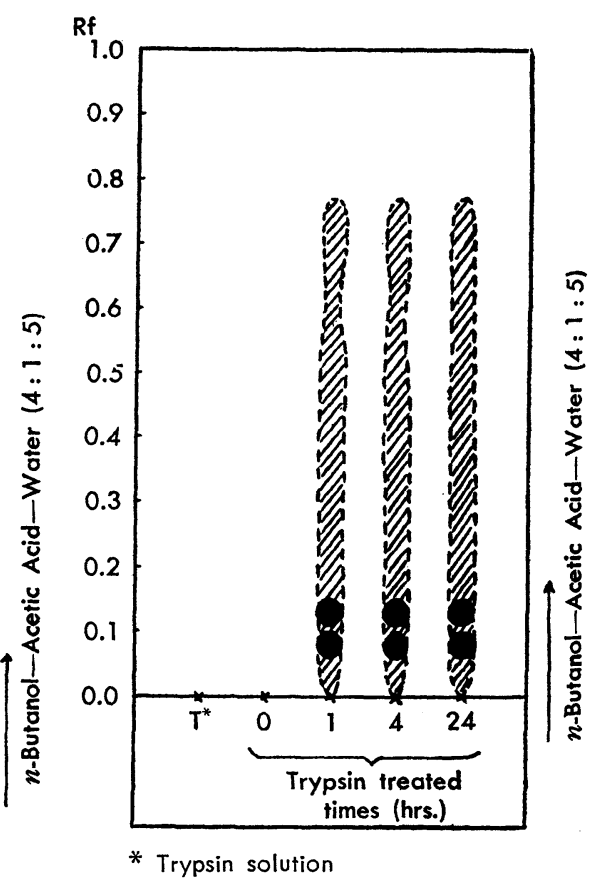

Fig. 4. Paperchromatogram of non-protein fraction of Parotin digested by trypsin 


\section{DISGUSSION}

The maximum wave length of ultraviolet absorption spectrum of Parotin in $\mathrm{pH} 8.0$ solution was similarly shown to that in $\mathrm{pH} 7.0$ described by Ito (1954). In Figure 2, the A curve showed the extinction of digested Parotin itself, the B showed the extinction of $\mathrm{pH} 5.4$ soluble non-Parotin fraction produced by the digestion of Parotin, and the $\mathrm{C}$ showed the extinction of non-protein fraction produced by the digestion of Parotin. Therefore, the differences between $\mathrm{A}$ and $\mathrm{B}$ shows the degradation of the Parotin molecule which was insoluble at $\mathrm{pH} 5.4$ in aqueous solution. And then, the differences between $\mathrm{A}$ and $\mathrm{C}$ indicates the decrease of protein portion in Parotin on the tryptic digestion. When the Parotin was digested by trypsin, at first the isoelectric point of it was rapidly changed, and secondly the non-protein fraction came from digested Parotin increased. The paper chromatogram of digested Parotin agreeds with the result of the analysis of the ultraviolet absorption spectrum. On the tryptic digestion, the changes of these chemical properties of Parotin were shown as fast as the diminution of leucocytes decreasing activity of Parotin, while the changes of them were shown faster than the diminution of serum calcium decreasing activity (Ito and Shinoda, 1958). Then, it seemed that the biological activity of Parotin on the digestion did not ever show a linear relation with the chemical or physico-chemical properties of it.

\section{SUMMARY}

The influence of tryptic digestion on the chemical and physico-chemical properties of Parotin were determined. The free amino-nitrogen content in Parotin was rapidly increased within $1 \mathrm{hr}$. The isoelectric point ( $\mathrm{pH}$ 5.4) of Parotin was easily changed on the digestion. The ultraviolet absorption of the trichloroacetic acid soluble fraction in digested Parotin was rapidly increased. By the paper chromatography, 2 or more hydrolyzates were recognized in non-protein fraction of the digested Parotin.

\section{REFERENCES}

Anson, M. L. (1938). J. Gen. Physiol. 22, 79.

Ito, Y. (1954). Endocrinol. Japon. 1, 1.

Ito, Y. and A. Mizutani. (1952). J. Pharm. Soc. Japan 72, 244.

Ito, Y. and M. Shinoda. (1958). Endocrinol. Japon. 5, 221. 